\title{
Practices, Housing and Diseases Within Indigenous Poultry Production in Eastern Cape, South Africa
}

\author{
Peter Ayodeji Idowu ${ }^{1}$, Maliviwe Mpayipheli ${ }^{1} \&$ Voster Muchenje $^{1}$ \\ ${ }^{1}$ Department of Livestock and Pasture Science, University of Fort Hare, Alice, Eastern Cape, South Africa \\ Correspondence: Maliviwe Mpayipheli, Department of Livestock and Pasture Science, University of Fort Hare, \\ Alice, Private Bag X1314, Eastern Cape, 5700, South Africa. E-mail: mmpayipheli@ufh.ac.za
}

Received: July 16, 2018

Accepted: September 9, $2018 \quad$ Online Published: October 15, 2018

doi:10.5539/jas.v10n11p111

URL: https://doi.org/10.5539/jas.v10n11p111

This research was financed by Govan Mbeki Research Development Centre (GMRDC).

\begin{abstract}
In an effort to improve the livelihood of indigenous farmers in South Africa, little input has been accorded to documentation and validation of some practices of poultry production farmers in Eastern Cape Province, South Africa which is the objective of this study. One hundred and Sixty (160) structured questionnaires were administered in six villages from two district municipalities using non-probabilistic (snowball) sampling method from July 2017 to June 2018. Results reveal that $73.1 \%$ of indigenous farmers are female, $24.38 \%$ reared mostly for household consumption, $48.1 \%$ flock ranges from 10-50. In addition, about $46.2 \%$ of farmers practiced semi-intensive rearing systems. Diseases $(63.52 \%)$ and Theft $(51.94 \%)$ are major challenges affecting most chickens. Most farmers used both ethno veterinary (Aloe ferox 32.5\%) and medicinal drugs (Terramycin 42.5\%) for treatment of diseases respectively. Correlation between diseases and housing was insignificant across different villages. The cleaning system, place of purchase and stage of purchase are highly significant across different villages. Most farming practices are positively correlated across different villages. There is need to assess farming practices adopted, this will help in proper planning and in maximizing profit across indigenous poultry production.
\end{abstract}

Keywords: indigenous poultry, diseases, rearing systems, rural poor, medication plan

\section{Introduction}

Indigenous poultry production assumes an integral agricultural role in meeting animal protein and income need of rural areas (McAinsh et al., 2004; Njenga, 2005; Olwande et al., 2010). In previous studies, indigenous poultry production has been grouped into four different rearing systems based on resources available, number of flock size, housing structure, vaccination plan and feeding system (Conan et al., 2012; Thieme et al., 2014). The groupings are small extensive scavengers (1-5 matured hen), unimproved scavengers (5-50 hens), semi intensive (50-200 chicken), and small scale intensive production (> 200 matured hen or $>100$ layers) (Conan et al., 2012; Thieme et al., 2014). Poultry production grouping reveal its total dependency on the personal preference or what best describe the farmers' intention. Furthermore, farmer's groupings can be maintained with low land area, minimal labour and little capital inputs. Such features make it acceptable by even the least privileged social strata of the rural population (Gueye, 1998; Anjum et al., 2012).

Poultry acceptability depends on its availability and affordability and this has sporadically increased its consumption. Regardless of the importance explained earlier, the consumption of poultry products is also known to take a prime role in erratic infections when contaminated (Mayers et al., 2017). Temperature changeability, stress, environmental harshness, stocking densities, housing structure has been stated as factors exposing poultry animals to infections (Mayers et al., 2017). Also, high mortality rate, host species low resistance, adulterated immune and health status, strain of diseases (bacterial, viral), environmental factors, housing, feeding, information and marketing are some of challenges faced by farmers (Gueye, 2004; Miller et al., 2015). And in most cases, such challenges are encouraged by lack of epidemiology records leading to reoccurring of diseases with no proper treatment and good managerial facilities to curb such infection (Sahin et al., 2015). Despite these challenges, indigenous poultry is greatly utilized in day to day protein consumption (Sahin et al., 2015). 
Although, such utilization depends on family occupation, of which most farmers are fully involved in poultry production which make poultry products locally accessible for consumption (FAO, 2010; Thieme et al., 2014).

In South Africa, disease causes great harm to communities from processed poultry products to live chickens ranging from 1.3-8.3\% loss of live poultry (Malatji et al., 2016). Nevertheless, there are no documentation and validation for practices embraced in indigenous poultry production. Although, some findings have been done on swine, veal calf and dairy farms in comparison to poultry related disease (Monecke et al., 2013). Disease prevalence with inability to trace them to their source and how to manage them has been a great challenge to indigenous poultry production in Eastern Cape Province. This study aims at revealing different housing structure, cleaning systems adopted, flock size and age groups and prevailing diseases coupled with control measures adopted by indigenous poultry farmers in Eastern Cape Province. This study was conducted based on the need for documentation and validation of indigenous poultry production practices for proper farming structure in area of study.

\section{Materials and Methods}

\subsection{Sampling Site}

This study was carried out in six villages in Eastern Cape Province. The villages were Ciko, Gosani, Dokodela and Dokodweni, Nqabarha and Ludondolo respectively. It is located amidst the coastal region of Eastern Cape Province with an area of $3,303 \mathrm{~km}^{2}$, characterized by average annual rainfall of 580-800 mm per annum with most occurring rainfall experienced in spring and summer months (ECDC, 2007; Nyoni \& Masika, 2012).

\subsection{Sampling Procedure}

The study was conducted from July 2017 to June 2018 in six villages present in two district municipalities of the Eastern Cape Province in South Africa (i.e. Mbhashe and Nyandeni). Non- probabilistic (snowball) sampling techniques were adopted by recognizing farmers that meet the criteria for study inclusion (Khapayi \& Celliers, 2016). Information was gathered after pre-visit test with deputy head of department of agrarian.

\subsection{Sample Size, Power and Precision}

Six villages were sampled with over 160 structured questionnaires. But 160 questionnaires were duly filled and thus analyzed for this study. These were administered through personal interviews with different households which practice poultry production irrespective of the sample size. Criteria for selection were basically farmers who reared indigenous breeds alone.

\subsection{Measures and Covariates}

Five trained enumerators coupled with an extension officer helped the investigator to conduct the research. Only those households who owned chickens and willing to participate in the research were considered. Information on village chicken production were gathered under the following categories: husbandry practiced, rearing system practices, health management and common challenges faced by smallholder farmers, vaccination method practiced, household demography, livestock inventory, roles of village chickens, housing and health management and agricultural extension services. Farmers' perceptions of village chicken production constraints were also gathered. Ethical clearance was duly applied for and granted (Ethical Reference Number: MPA031SIDO01) before the commencement of the study, thus, the safety of the participant and animals were greatly considered.

\subsection{Research Design}

Collected data was analyzed using Statistical Analysis System (SAS, 2003). Frequency procedure was used for descriptive statistics. Cross tabulations was used to reveal the relationships between flock size and age groups. Means procedures were computed to analyze age range of poultry farmers, rearing system adopted, household demography, housing structure and poultry related diseases by indigenous poultry farmers. Correlation analysis was done to show association between disease and housing methods. Tukey's test was used for multiple comparisons of means between cleaning system, stage of purchase, place of purchase and rearing system adopted. 


\section{Results and Discussion}

Poultry farming is majorly practiced and best maximized by women in South Africa (73.1\%). It is assumed that poultry management is female occupation because they are known to be at home to take care of the family and to manage poultry production. The same observation was recorded in Cameroon, Gambia, Senegal and Morocco (Agbede et al., 1995; Andrews, 1999; Missohou et al., 2002; Issa et al., 2013). However, contrary result was observed in Niger. More men are into poultry production than women; this could be as result of quick response of men to survey than women (Amadou et al., 2010).

Females of age group (31-50years) who are married with only primary level of education are predominantly involved in poultry farming (Table 1). This is believed to be a form of assistance to financial need of the each household. The same age group was reported by Nyoni and Masika (2012). This study also reveals that men own cattle, goats and sheep, these are generally relatively low in numbers in comparison to chickens. Hence, the latter were regarded as very important by most farmers (Hossen, 2010). Most young ones are sent to school and are not involve in poultry production this development may improve indigenous poultry production as new techniques could be applied by learned upcoming farmers.

Table 1. Demographic representation of indigenous poultry in Eastern Cape Province

\begin{tabular}{ll}
\hline Demographic & Frequency (\%) \\
\hline Gender & $117(73.1)$ \\
Female & $43(28.88)$ \\
Male & $6(3.75)$ \\
\hline Age & $36(22.5)$ \\
$\leq 19$ & $65(40.63)$ \\
$20-30$ & $53(33.13)$ \\
$31-50$ & $30(18.75)$ \\
$\geq 51$ & $38(23.75)$ \\
\hline Level of Education & $65(40.63)$ \\
Illiterate & $53(33.13)$ \\
Read and Write & \\
Primary & $7(4.38)$ \\
Secondary & $85(53.13)$ \\
Employment & $37(23.13)$ \\
Employed & $31(19.38)$ \\
Unemployed & \\
Self employed & \\
Retired &
\end{tabular}

Indigenous poultry are predominantly kept for consumption purposes $(24.38 \%)$ and egg production (23.13\%) respectively (Table 2). This can be attributed to the availability of chicken meat and eggs as a rich source of protein and the fact that they are perceived to be more nutritious. This finding is in agreement to report of (Nyoni and Masika, 2012; Issa et al., 2013). Farmers reported selling poultry birds for the purpose of generating income to meet unplanned needs, food security and to assist fellow farmers in need. All the reasons for keeping chicken were also reported by Mwale and Masika (2009), Olwande et al. (2010), and Mtileni et al. (2012) respectively. In addition, slaughtering easiness and ability to consume within a short time, without stress about storage facilities are responsible for high consumption rate. This was also stated by Nyoni and Masika (2012). The result of this study also found that chickens are used as a gift, kept for hatching or breeding purposes and for religious purposes (Table 2). According to Olwande et al. (2010) both live and slaughtered chicken are used as gifts amidst farmers. However, the report of this study stated that chickens are used for traditional and/or religious purposes. This finding negates report of Nyoni and Masika (2012) who reported that chicken are not used for traditional or religious purposes. 
Table 2. Reasons for keeping chickens by poultry farmers $(\mathrm{N}=160)$ in Eastern Cape

\begin{tabular}{ll}
\hline Reason for keeping chickens & Number $(\%)$ \\
\hline Sales for income & $33(20.63)^{3}$ \\
Hatching/Breeding & $22(13.75)^{4}$ \\
Egg Production & $37(23.13)^{2}$ \\
Home Consumption & $39(24.38)^{1}$ \\
Gift/Entertainment & $18(11.25)^{5}$ \\
Cultural/Religious & $11(6.88)^{6}$ \\
Total & $160(100)$ \\
\hline
\end{tabular}

Note. The superscript was used to explain reasons for keeping chicken by poultry farmers based on order of percentage.

Average range of flock size per household in the current study is 10-50 (Table 3). This is in accordance with Hossen (2010), and Issa et al. (2013) who reported 16.3 and 16.8 flock size respectively. Based on our findings, the small flock size is related to low feed conversion rate of indigenous chicken, disease occurrence from feeding of diseased ants or insects and lack of capital to practice large scale farming. This was also stated by Phiri et al. (2007) in similar study.

Flock size was defined by Hossen (2010) as heterogeneous state of flock composition which shows different age group. It is a great factor that reveals dynamism across poultry production. In area of study farming experience, breeding goal and available resources are factors determining flock size of indigenous poultry farmers (Table 3).

Table 3. Distribution of poultry farms maintained by indigenous poultry farmers in Eastern Cape Province in relation to flock size and age $(\mathrm{N}=160)$

\begin{tabular}{lllllll}
\hline \multirow{2}{*}{ Flock size } & \multicolumn{5}{c}{ Age groups of chickens in weeks and number (\%) of farms } \\
\cline { 2 - 7 } & $1-2$ & $3-6$ & $7-10$ & $\geq 10$ & MA & Total \\
\hline $0-10$ & $1(0.6)$ & $1(0.6)$ & $8(5.0)$ & $9(5.6)$ & $6(3.8)$ & $25(15.6)$ \\
$10-50$ & $1(0.6)$ & $6(3.8)$ & $23(14.4)$ & $37(23.1)$ & $10(6.2)$ & $77(48.1)$ \\
$51-100$ & $3(1.9)$ & $2(1.2)$ & $8(5.0)$ & $16(10.0)$ & $6(3.8)$ & $35(21.9)$ \\
$101-200$ & $0(0)$ & $1(0.6)$ & $6(3.8)$ & $1(0.6)$ & $1(0.6)$ & $9(5.6)$ \\
$>200$ & $1(0.6)$ & $1(0.6)$ & $2(1.2)$ & $5(3.1)$ & $5(3.1)$ & $14(8.8)$ \\
Total & $6(3.8)^{5}$ & $11(6.9)^{4}$ & $47(29.4)^{2}$ & $68(42.5)^{1}$ & $28(17.5)^{3}$ & $160(100)$ \\
\hline
\end{tabular}

Note. Figures in parentheses are percentages. Mean values with different superscripts differ significantly $(\mathrm{p}<$ $0.05)$.

$\mathrm{MA}=$ multi-age. NB: each number represent farming households not chickens.

Rearing system adopted by indigenous poultry farmers are semi-intensive system (46.2\%), cage confinement (28.1\%), unimproved scavengers $(16.2 \%)$ and free range or extensive system $(9.4 \%)$. This finding is in contrast to Herve-Claude (2010) who reported that $83 \%$ of farmers use free ranging system. Most farmers prefer to allow their chickens to graze around during the day and kept in poultry houses at night (Table 4). This is believed to reduce cost of production but invariably also affect profit turnover of poultry production. This finding is in agreement to Issa et al. (2013). In addition, different breeds of chicken are raised within area of study: Ovambo breeds (38\%), Venda (21\%), Potchefstroom Kooekok $(23 \%)$, and naked neck $(19 \%)$. These breeds were also reported by Mtileni et al. (2012) in similar study. 
Table 4. Rearing system practiced by farmers in Eastern Cape Province

\begin{tabular}{ll}
\hline Rearing system & Number $(\%$ of respondents) \\
\hline Cage-Confinement & $45(28.1)^{2}$ \\
Semi Intensive & $74(46.2)^{1}$ \\
Unimproved Scavengers & $26(16.2)^{3}$ \\
Extensive & $15(9.4)^{4}$ \\
Total & $160(100)$ \\
\hline
\end{tabular}

Note. The superscript was used to explain rearing systems adopted by poultry farmers based on order of percentage.

Table 5 reveals the relationship between housing methods adopted by indigenous poultry farmers. Housing methods adopted are positively insignificant in relation to disease prevalence at $p \leq 0.005$ this shows that housing method adopted is not affected by disease in poultry production. It can be deduced from this study that housing methods adopted has no direct impact on disease prevalence. Wilson (2010) reported that there may be other farming practices which results in disease prevalence.

Table 5. Effect of housing on disease prevalence in indigenous poultry production

\begin{tabular}{lllll}
\hline Parameters & Minimum & Maximum & Mean \pm Sd & Corr. Coeff. \\
\hline Diseases & 1 & 13 & $6.668 \pm 3.73$ & NS \\
Housing & 1 & 6 & $3.475 \pm 1.54$ & \\
\hline
\end{tabular}

Note. $\mathrm{p} \leq 0.005$ at 2 tailed level of significance. NS means not significant.

Table 6 shows poultry housing structure embraced by indigenous poultry farmers. This study observed use of half block and half zinc, half zinc and half wire, inside the house, no definite housing, half zinc and half wood. This finding negates study by Aganga et al. (2000) who reported that poultry farmers resorted to cheap and locally available materials such as mud, wooden poles, and corrugated sheets only. The observed improvement could be as a result of farmers experience and improvement of indigenous farmers by intervention of extension agents, exposure to trainings and need to reduce disease occurence. Indigenous poultry farmers attach more importance to poultry housing than in previous years by providing more comfortable housing for chicken. Nevertheless, nest and feeders for brooding activities are not yet available in most poultry farm. Predation such as cat, dog, and snake do affect survivability in the area of study. This has lead to great loss by posing lots of threats to success of indigenous poultry production.

Table 6. Distribution of level of education with housing structure

\begin{tabular}{|c|c|c|c|c|c|c|c|c|c|}
\hline \multirow[b]{2}{*}{ Level of Education } & \multicolumn{9}{|c|}{ Housing structure } \\
\hline & $\begin{array}{l}\text { Half block, } \\
\text { half zinc }\end{array}$ & $\begin{array}{l}\text { Half zinc, } \\
\text { half wire }\end{array}$ & $\begin{array}{l}\text { Inside the } \\
\text { house }\end{array}$ & $\begin{array}{l}\text { No definite } \\
\text { housing }\end{array}$ & $\begin{array}{l}\text { Half zinc, } \\
\text { half wood }\end{array}$ & Local cage & Windowed & $\begin{array}{l}\text { Uncompleted } \\
\text { building }\end{array}$ & Total $(\%)$ \\
\hline Illiterate & 5 & 13 & 6 & 1 & 0 & 3 & 1 & 1 & $30(18.75)$ \\
\hline Read and Write & 2 & 15 & 6 & 4 & 1 & 5 & 1 & 4 & $38(23.75)$ \\
\hline Primary & 10 & 26 & 6 & 7 & 3 & 2 & 4 & 1 & $59(36.87)$ \\
\hline Secondary & 5 & 9 & 3 & 7 & 2 & 2 & 5 & 0 & $33(20.63)$ \\
\hline Total & 22 & 63 & 21 & 19 & 6 & 12 & 11 & 6 & $160(100)$ \\
\hline
\end{tabular}

Table 7 shows various stages of purchase according to different households and based on available resources. Most farmers prefer purchasing matured hen $(34.38 \%)$, followed by multi age or undefined age $(33.13 \%)$, few weeks' old $(21.25 \%)$ and day old chicks $(11.25 \%)$ in that order. Most farmers prefer to buy matured hen due to unavailability of hatching centre, no knowledge about brooding activities and most farmers do not sell day old chicks. Coefficient of correlation was done across some farming practices. Cleaning system structure adopted was negatively insignificant to place of purchase and stage of purchase which means cleaning strategy has no relationship to where chicken was purchased. But rearing system adopted has a huge impact on how farmers 
decide to clean the poultry housing. Survival of chicken based on age at purchase is strongly related to rearing systems adopted than cleaning systems and place of purchase. This is in accordance to King'Ori et al. (2010).

Table 7. Correlation between cleaning system, place of purchase, stage of purchase and rearing system

\begin{tabular}{lllll}
\hline Variables & Cleaning System & Place of Purchase & Stage of purchase & Rearing System \\
\hline Cleaning System & - & NS & NS & $* * *$ \\
Place of Purchase & NS & - & NS & $* *$ \\
Stage of Purchase & NS & NS & - & $* * *$ \\
Rearing System & $* * *$ & $* *$ & $* * *$ & - \\
\hline
\end{tabular}

Note. Level of significance $(* *)$ level of significance at $\mathrm{P} \leq 0.05(* * *)$ level of significance at $\mathrm{P} \leq 0.01$.

Both ethno-veterinary medicines and medicinal drugs are used by indigenous poultry farmers. Some farmers use both medicinal plant and drugs for treatment. Figure 1 shows that most indigenous poultry farmers embraced the use of medicinal herb and medicinal drug in combating diseases. Such drugs used are colprin (12.5\%), amprol (30\%), Sb3 (16.9\%), care (15.6\%) and terramycin (42.5\%). In addition, ethno-veterinary medicines used are aloe ferox (32.5\%), aloe vera (26.35\%), elephantine (7.5\%), garlic (4.38\%), buttercup (5\%), cape gold (6.88\%). Both medicinal drugs and herbs have helped greatly in reducing the levels of disease across indigenous poultry production. However, this finding negates report by Issa et al. (2013) who observed usage of onions, pepper, and mahogany leaves. Agbede et al. (1995), and Buldgen et al. (1992) stated that medical prophylaxis are not used but uses human drugs such as antibiotics and anti malaria are used only. Nevertheless, usage of drugs and ethno-veterinary drugs are based on availability, method of usage, price and personal preference of farmers.

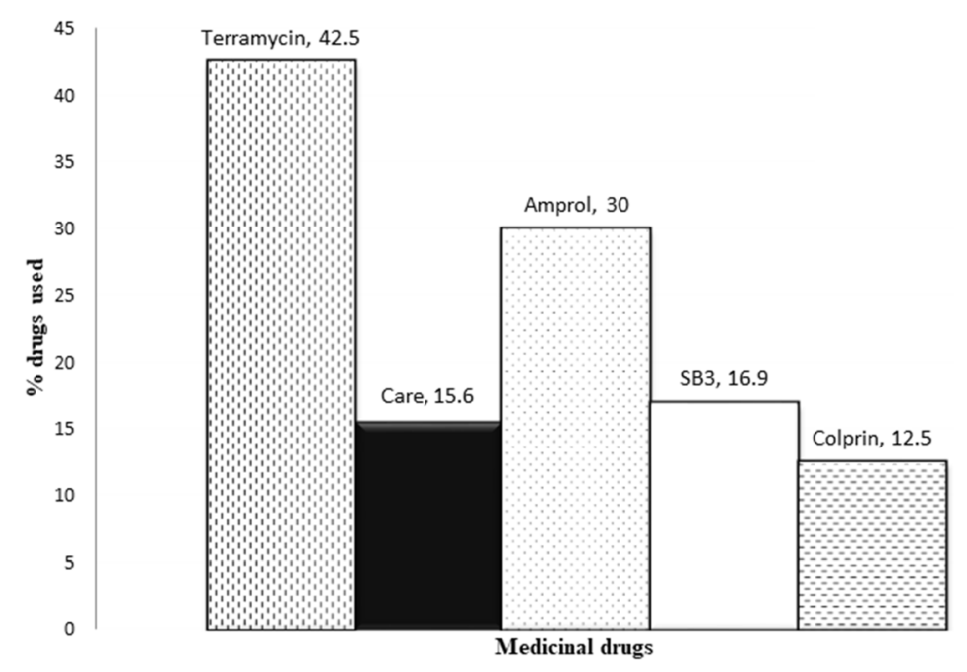

Figure 1. Medicinal drugs used in indigenous poultry production 


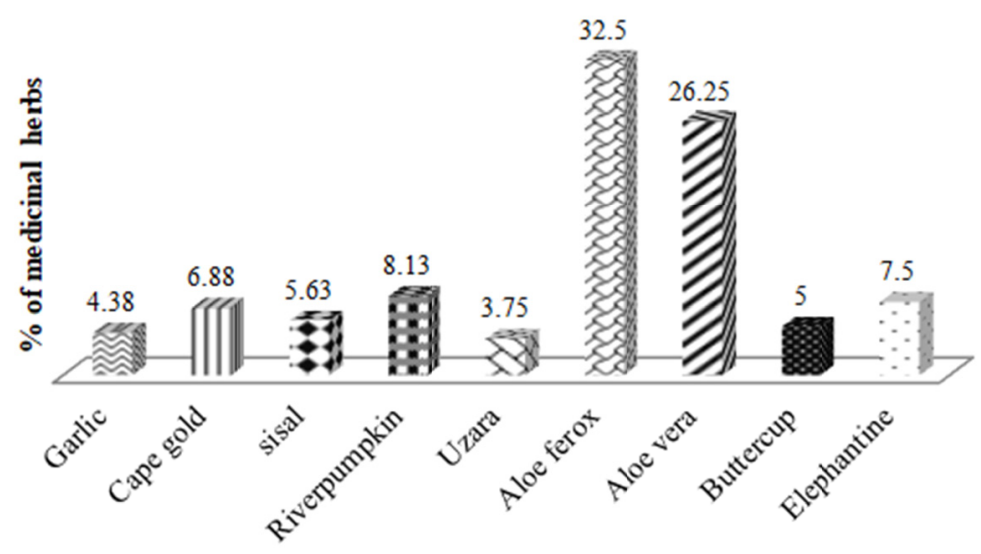

Medicinal herbs

Figure 2. Ethno-veterinary medicines used in indigenous poultry production

Levels of vaccination is represented in Figure 3, this differ within the production system which are incomplete vaccination (43.8\%), no vaccination (36.9\%) and complete vaccination (19.4\%). This result is in accordance with the report of Issa et al. (2013) that most of the farmers practice incomplete vaccination and no vaccination. However, in area of study, level of vaccination has increased within indigenous poultry production in comparison to Adebayo et al. (2013).

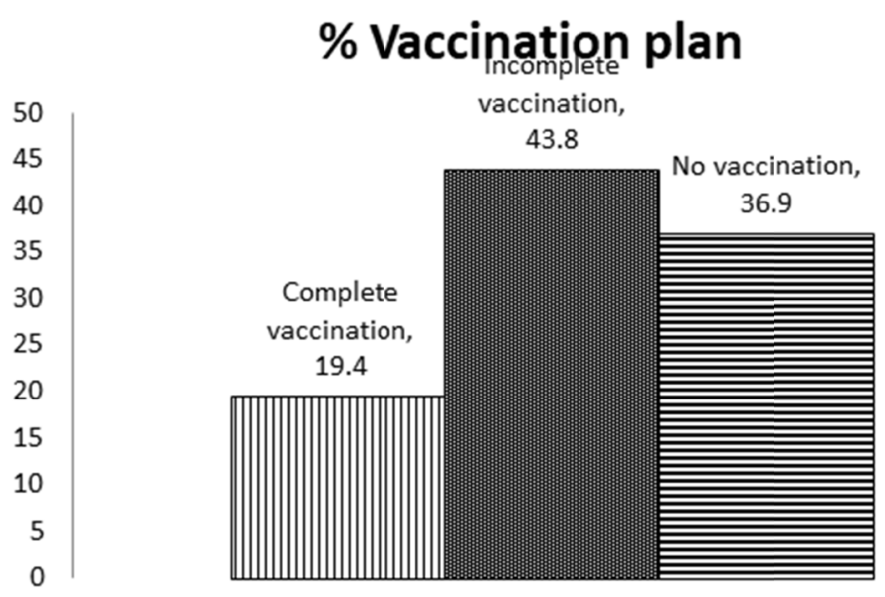

Figure 3. Shows variation of vaccination plans adopted by indigenous poultry farmers

Respiratory gasping can be attributed to Newcastle disease which accounted for most prevailing disease in the area of study. This is in accordance to a similar study in Rwanda and Ethiopia (Mazimpaka et al., 2018; Hailemichael et al., 2017). This study observed incidence of no disease, fever (listeria), diarrhea (Salmonella) and blood in stool (Escherichia coli), nasal discharge (Avian Influenza), and loss of appetite (Staphylococcus) mostly in summer season. In a similar study in Nigeria, Botswana and Kenya, more disease outbreak are recorded (Adebayo et al., 2013; Moreki et al., 2010; King'Ori et al., 2010). In addition, stiff neck (Listeria), pain in movement (Staphylococcus), misshapen eggs (Avian Influenza) are mostly prevalent in winter. In area of study, some farmers reported stress related disease (3.13\%) and No disease (14.38\%). Such instance was reported by Yongola (2006) Figure 4. 


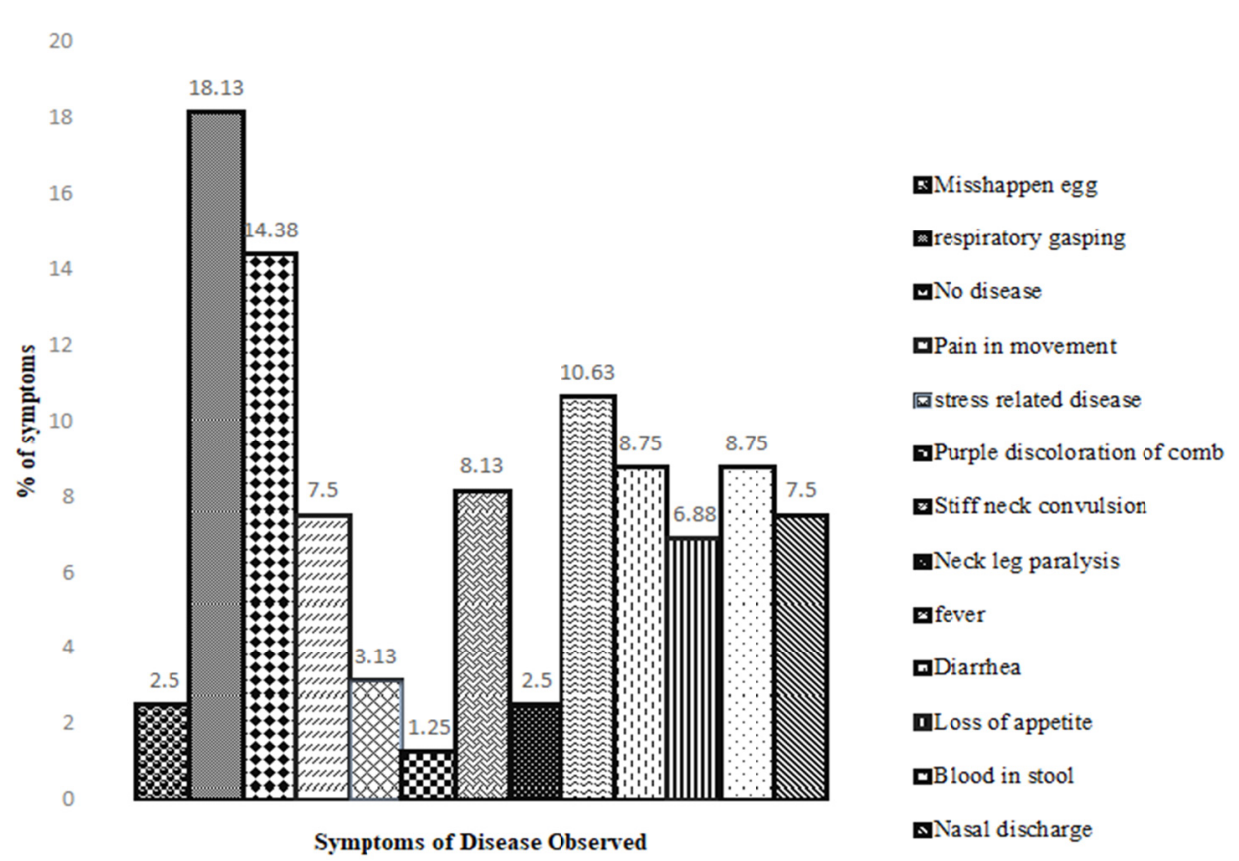

Figure 4. Shows poultry related disease observed in indigenous poultry production

In this study, disease (63.5\%) was accounted as the highest challenge faced by farmers especially with chicks having fever, cold related issue. It was observed that state of feather determines level of resistance to some diseases. Similar report was recorded by Peguri and Coon (1993). High level of theft was recorded in area of study. Most of the farmers reported theft as a great challenge affecting productivity and profit. In addition, even in cases of enclosed building theft issues were evident.

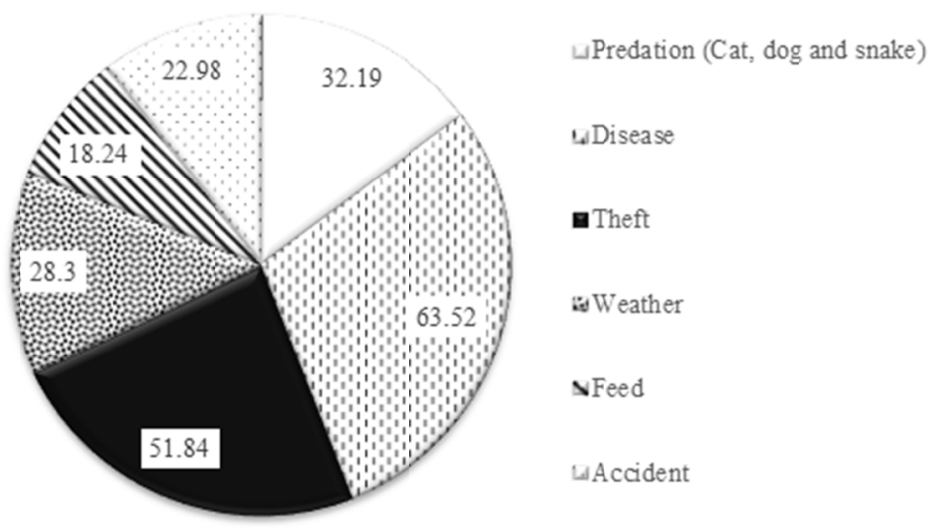

Figure 5. Limiting factors against poultry productivity

Figure 6 shows places of purchase of chickens. $34.38 \%$ were purchased at nearby markets, $33.13 \%$ from fellow farmers while $21.23 \%$ were purchased from department of Agriculture through extension agents and $11.25 \%$ from hatchery. Most of indigenous poultry farmers are void of knowledge about brooding activities and some are not financially capable of buying brooding facilities thus discourage them from buying day old chicks (Issa et al., 2013). In this study, some villages have centralized brooding centre while some farmers prefer to purchase their poultry from fellow farmers than in hatchery. This was based on availability and closeness to seller. Similar report was recorded by Nyoni and Masika (2012). Figure 7 shows cleaning systems adopted by indigenous poultry farmers which are daily cleaning $(11.86 \%)$, two days interval $(20 \%)$ cleaning, three days interval cleaning (8.75\%), weekly cleaning (16.88\%), Never clean (33.13\%) and Anyhow (9.38\%). Most farmers 
attached no importance to cleaning of poultry house thus embraced unstructured cleaning system; this could have resulted in disease prevalence.

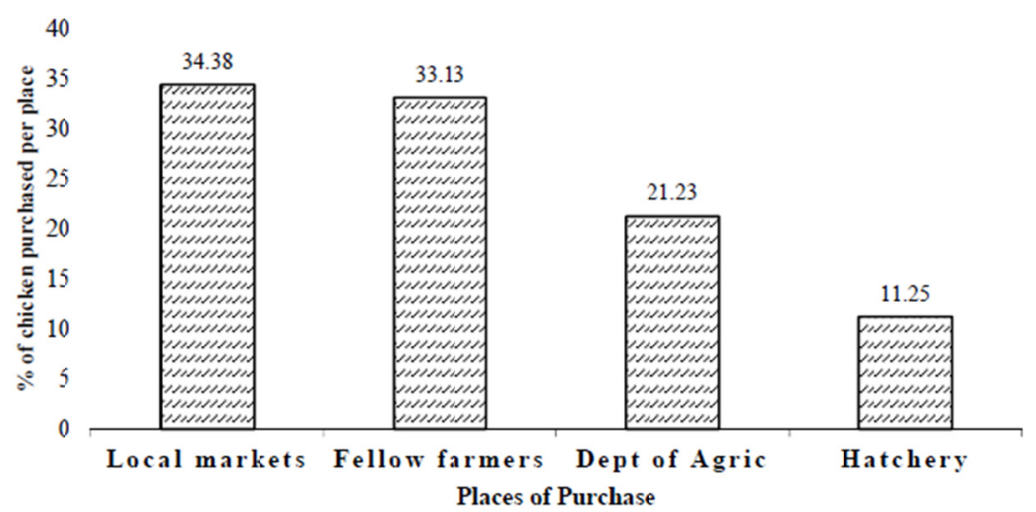

Figure 6. Place of purchase of chickens for production

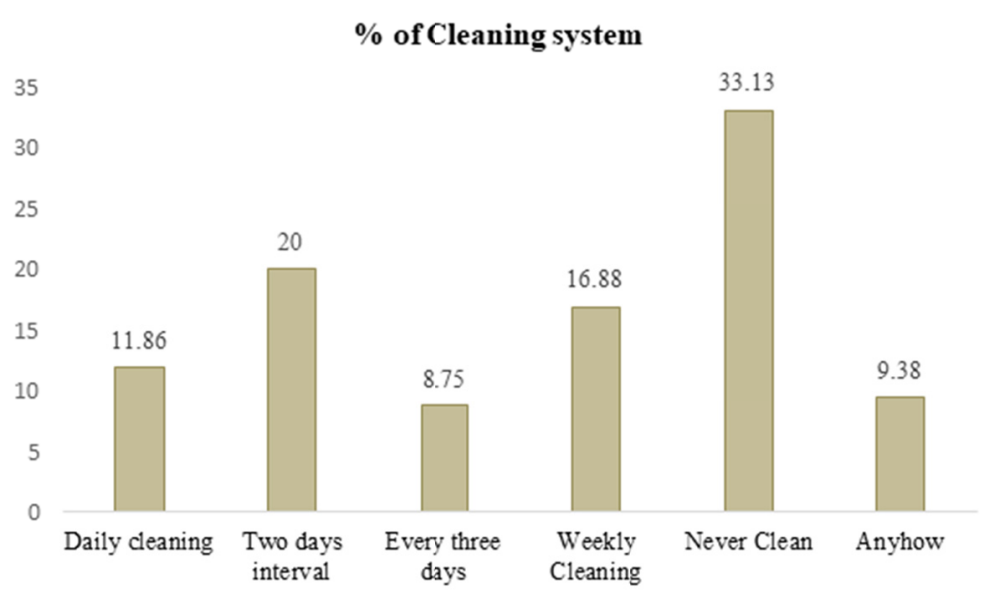

Figure 7. Cleaning structure adopted by indigenous poultry farmers

\section{Conclusion}

> Indigenous poultry production is majorly practiced by women. It can be said that education and high unemployment rate are basis for involvement.

$>$ Poultry production is practiced majorly to meet up protein need thus lead to high level of consumption of chickens and eggs among other products.

$>$ Different housing structure are adopted based on available resources, flock size and education levels.

$>$ Levels of disease are decreasing though disease is still a major threat aside theft and other predators.

> Vaccination plans are on-going but in most cases are incomplete and some are still not vaccinating.

$>$ There is a positive correlation between rearing systems and cleaning systems.

$>$ Ethno-veterinary medicines are used for treatment of diseases but with no method of measurement.

\section{Recommendation}

Attention should be on how to provide nest, feeders for brooding activities, hatchery centers and centralized feedmill for feed availability.

$>$ Indigenous farmers should cultivate habitual cleaning practices in order to limit disease prevalence across poultry production. 
$>$ Educated farmers should be encouraged by provision of capitals and incentives in order to improve poultry producton across diferent households.

\section{Acknowledgements}

This project was financed by Govan Mbeki Research Development Centre (GMRDC), University of Fort Hare, South Africa. Grant number: C346. Thanks to Mr. Maliviwe Mpayipheli, for critic review, correction. I appreciate Prof Voster Muchenje for support throughout the writing period. Special thanks to my wife Idowu Patience Adeola who helped in proper arrangement in the discussion session.

\section{References}

Adebayo, S. A., Ogunlade, I., \& Fayeye, T. R. (2013). Scope and Common Diseases of Rural Poultry Production by Rural Women in Selected Villages of Kwara State, Nigeria. International Journal of Poultry Science, 12(3), 126-129. https://doi.org/10.3923/ijps.2013.126.129

Aganga, A. A., Omphile, U. J., Malope, P., Chabanga, C. H., Motsamai, G. M., \& Motsumi, L. G. (2000). Traditional poultry production and commercial broiler alternatives for small-holder farmers in Botswana. Livestock Research for Rural Development, 12(4), 1-8.

Agbede, G. B., Teguia, A., \& Manjeli, Y. (1995). Survey on traditional poultry production in Cameroon. Tropicultura, Belgium.

Amadou, B. M., Idi, A., \& Benabdeljelil, K. (2011). Characterization of traditional poultry farming in Niger. World's Poultry Science Journal, 67(3), 517-530.

Andrews, P. (1990). October. Rural poultry development in The Gambia. CTA-Seminar proceedings on smallholder rural poultry production (pp. 9-13).

Anjum, M. A., Khan, S. H., Sahota, A. W., \& Sardar, R. (2012). Assessment of aflatoxin B1 in commercial poultry feed and feed ingredients. J. Anim. Plant Sci, 22(2), 268-72.

Buldgen, A., Detimmerman, F., Sall, B., \& Compère, R. (1992). Study of demographical and zootechnical parameters of local hens in the Ground-Nut Basin of Senegal. Revue d'Elevageet de Medecine Veterinaire des Pays Tropicaux, France.

Conan, A., Goutard, F. L., Sorn, S., \& Vong, S. (2012). Biosecurity measures for backyard poultry in developing countries: A systematic review. BMC Veterinary Research, 8(1), 240. https://doi.org/10.1186/17466148-8-240

ECDC (Eastern Cape Development Cooperation). (2007). Climate and Regional distribution statistics. Retrieved from http://www.ecdc.co.za/easterncape/ec.asp?pageid $=22$

FAO. (2010). In B. D. Scherf (Ed.), World Watch List of Domestic Animal Diversity. Food and Agriculture Organization of the United FAO Nations (FAO), Rome, Italy.

Hailemichael, A., Gebremedhin, B., \& Tegegne, A. (2017). Status and drivers of village poultry production and its efficiency in Ethiopia. NJAS-Wageningen Journal of Life Sciences, 83, 30-38. https://doi.org/10.1016/j.njas. 2017.09.003

Herve-Claude, L. P. (2010). Evaluation of Strategies on a Farm Animal Census in the Eastern Cape Province, South Africa (p. 152). Institute of Biometry, Epidemiology and Information Processing, University of Veterinary Medicine of Hannover, Hannover.

Hossen, M. J. (2010). Effect of management intervention on the productivity and profitability of indigenous chickens under rural condition in Bangladesh. Livestock Research for Rural Development, 22, 192.

Issa, A. Y., Mopate, L. Y., Ayssiwede, S. B., \& Missohou, A. (2013). Production practices, constraints and performance in traditional chicken breeding in chad. International Journal of Poultry Science, 12(6), 367-376. https://doi.org/10.3923/ijps.2013.367.376

Khapayi, M., \& Celliers, P. R. (2016). Factors limiting and preventing emerging farmers to progress to commercial agricultural farming in the King William's Town area of the Eastern Cape Province, South Africa. South African Journal of Agricultural Extension, 44(1), 25-41.

King'ori, A. M., Wachira, A. M., \& Tuitoek, J. K. (2010). Indigenous chicken production in Kenya: A review. International Journal of Poultry Science, 9(4), 309-316. https://doi.org/10.3923/ijps.2010.309.316

Lin, J. (2009). Novel approaches for Campylobacter control in poultry. Foodborne Pathogens and Disease, 6(7), 755-765. https://doi.org/10.1089/fpd.2008.0247 
Malatji, D. P., Tsotetsi, A. M., van Marle-Köster, E., \& Muchadeyi, F. C. (2016). A description of village chicken production systems and prevalence of gastrointestinal parasites: Case studies in Limpopo and KwaZulu-Natal provinces of South Africa. Onderstepoort Journal of Veterinary Research, 83(1), 1-8. https://doi.org/ 10.4102/ojvr.v83i1.968

Mayers, J., Mansfield, K. L., \& Brown, I. H. (2017). The role of vaccination in risk mitigation and control of Newcastle disease in poultry. Vaccine, 35(44), 5974-5980. https://doi.org/10.1016/j.vaccine.2017.09.008

Mazimpaka, E., Tukei, M., Shyaka, A., \& Gatari, E. N. (2018). Poultry production and constraints in Eastern Province of Rwanda: Case study of Rukomo sector, Nyagatare district. Tropical Animal Health and Production, 50(4), 753-759. https://doi.org/10.1007/s11250-017-1491-5

McAinsh, C. V., Kusina, J., Madsen, J., \& Nyoni, O. (2004). Traditional chicken production in Zimbabwe. World's Poultry Science Journal, 60(2), 233-246. https://doi.org/10.1079/WPS20040018

Miller, P. J., Haddas, R., Simanov, L., Lublin, A., Rehmani, S. F., Wajid, A., ... Afonso, C. L. (2015). Identification of new sub-genotypes of virulent Newcastle disease virus with potential panzootic features. Infection, Genetics and Evolution, 29, 216-229.

Missohou, A., Dieye, P. N., \& Talaki, E. (2002). Rural poultry production and productivity in Southern Senegal. Livestock Research for Rural Development, 14(2).

Monecke, S., Ruppelt, A., Wendlandt, S., Schwarz, S., Slickers, P., Ehricht, R., \& de Jäckel, S. C. (2013). Genotyping of Staphylococcus aureus isolates from diseased poultry. Veterinary Microbiology, 162(2-4), 806-812.

Moreki, J. C. (2010). Village poultry production in Serowe-Palapye sub-district of Botswana. Livestock Research for Rural Development, 22(3), 46.

Mtileni, B. J., Muchadeyi, F. C., Maiwashe, A., Chimonyo, M., Mapiye, C., \& Dzama, K. (2012). Influence of socioeconomic factors on production constraints faced by indigenous chicken producers in South Africa. Tropical Animal Health and Production, 45(1), 67-74. https://doi.org/10.1007/s11250-012-0175-4

Mwale, M., \& Masika, P. J. (2009). Ethno-veterinary control of parasites, management and role of village chickens in rural households of Centane district in the Eastern Cape, South Africa. Tropical Animal Health and Production, 41(8), 1685-1693. https://doi.org/10.1007/s11250-009-9366-z

Njenga, S. K. (2005). Productivity and socio-cultural aspects of local poultry phenotypes in coastal Kenya (Doctoral dissertation, Royal Veterinary and Agricultural University, Network for Smallholder Poultry Development).

Nyoni, N. M. B., \& Masika, P. J. (2012). Village chicken production practices in the amatola basin of the Eastern Cape Province, South Africa. African Journal of Agricultural Research, 7(17), 2647-2652.

Olwande, P. O., Ogara, W. O., Okuthe, S. O., Muchemi, G., Okoth, E., Odindo, M. O., \& Adhiambo, R. F. (2010). Assessing the productivity of indigenous chickens in an extensive management system in southern Nyanza, Kenya. Tropical Animal Health and Production, 42(2), 283-288. https://doi.org/10.1007/s11250-009-9418-4

Peguri, A., \& Coon, C. (1993). Effect of feather coverage and temperature on layer performance. Poultry Science, 72(7), 1318-1329. https://doi.org/10.3382/ps.0721318

Phiri, I. K., Phiri, A. M., Ziela, M., Chota, A., Masuku, M., \& Monrad, J. (2007). Prevalence and distribution of gastrointestinal helminths and their effects on weight gain in free-range chickens in Central Zambia. Tropical Animal Health and Production, 39(4), 309-315. https://doi.org/10.1007/s11250-007-9021-5

Sahin, O., Kassem, I. I., Shen, Z., Lin, J., Rajashekara, G., \& Zhang, Q. (2015). Campylobacter in poultry: Ecology and potential interventions. Avian Diseases, 59(2), 185-200. https://doi.org/10.1637/11072032315-Review

SAS. (2003). Statistical Analysis System. SAS Institute Inc., Cary, North Carolina, USA

Thieme, O., Sonaiya, F., Rota, A., Guèye, E. F., Dolberg, F., \& Alders, R. (2014). Chapter 1: Defining family poultry production systems and their contribution to livelihoods. FAO Animal Production and Health: Decision Tools for Family Poultry Development (pp. 3-8). Food and Agriculture Organisation of United Nations, Australia.

Wilson, R. T. (2010). Poultry production and performance in the Federal Democratic Republic of Ethiopia. World's Poultry Science Journal, 66(3), 441-454. https://doi.org/10.1017/S0043933910000528 


\section{Copyrights}

Copyright for this article is retained by the author(s), with first publication rights granted to the journal.

This is an open-access article distributed under the terms and conditions of the Creative Commons Attribution license (http://creativecommons.org/licenses/by/4.0/). 